\title{
GENDER DYSPHORIA: A MEDICAL AND ETHICAL PERPLEXITY AS DISTINCT FROM REALITY AND THE RATIONAL APPROACH FOR MUSLIM YOUNG PEOPLE
}

\author{
Najla Taslim ${ }^{1}$, Arthur D. Canales ${ }^{2} \&$ Shrooq Mohamed T. Alshehab ${ }^{1}$ \\ ${ }^{I}$ Department of Pharmacology, College of Clinical Pharmacy, Imam Abdulrahman bin Faisal University, \\ Dammam, Saudi Arabia \\ ${ }^{2}$ Department of Theology \& Philosophy, Marian University, Indianapolis, USA
}

received: 31.1.2021;

revised: 23.3.2021;

accepted: 30.3 .2021

\section{SUMMARY}

Gender dysphoria (GD), a conflict between one's self-perceived gender identity and the biological sex has been a wholly enigma and a source of contention between experts of various disciplines since long. This is a narrative review of the medical literature utilizing PubMed, Scopus, and Web of science databases, on the social status of GD patients, their therapeutic options, as well as the medical and ethical debate on GD that are of especial interest to the Muslim readers.

Gender dysphoric patients or transgender people have a long history of social discrimination, marginalization, abuse, and neglect all around the world. Currently, large scale social developments supporting of transgender rights are rapidly underway in the west. Clinical evidence-based guidelines have also been published and are available for the management of GD, albeit with some medical and ethical concerns. On the other hand, the transgender community is continued to suffer profoundly in the developing and majority of Muslim nations, due to generalized unawareness, neglect, cultural and religious boundaries on this issue. Currently, Muslim youth or young adults are showing passionate interest in GD and are actively seeking information to comprehend its complexities, but they face more dilemma on this matter than the people in the West.

This article addresses and discusses key transgender issues and controversies and provides a logical explanation that demonstrates that GD is real medical condition needing attention and that its treatment guidelines are justified. We hope this article will stimulate a new and broader perspective in minds of young Muslims and will urge them to take pragmatic steps in alleviating the travails of long-suffering and neglected transgender community.

Key words: gender dysphoria - transgender - Muslim countries - Islamic countries - Muslims

\section{INTRODUCTION}

Gender dysphoria (GD) (previously known as gender identity disorder) is defined as an extremely distressful psychological condition evolving from a person's perception that they are "trapped" in a wrong body and belong to the opposite sex (American Psychiatric Association 2013). For instance, a male with GD strongly believes or feels that he is a woman and similarly with a female experiencing GD. The intense emotional pain associated with GD may be severe enough to cause functional impairment in peoples' lives. Gender dysphoria patients are commonly referred to as transgender (American Psychiatric Association 2016).

Recently, GD awareness is growing; Western countries are opening up to transgender people and talking about the issues that transgender folk experience. Sociopolitical reforms favoring transgender rights are rapidly taking place in the West and medical assistance is freely accessible to those opting to transform their bodies in line with their gender expression (National Gay and Lesbian Task Force 2008, Reisner et al. 2015a). Undoubtedly, major changes are observable in the West, but a breakthrough acceptance or awareness is still far away. Similar to the situation elsewhere in the world, GD has been contested and is a culturally sensitive topic in Muslim societies (Ishak \& Haneef 2014, Saeed et al. 2018). Awareness about GD varies dramatically among Muslim countries with some showing legal acceptance; some rejection and others simply choose to remain oblivious to the existence and needs of transgender folks (Polat 2005, Wong 2012, Saeed et al. 2018)

Retrospectively, a vast majority of Muslim countries have had shunned transgender discussion and mention of transgender people altogether as evidenced by a stark lack of research output and media coverage of any sort on this matter. Recently, younger generation of Muslim youth or young adults are showing keen interest in understanding and learning about GD, but simultaneously, they are confounded by diametrically opposing religious and sociocultural transgender views within Islamic denominations (Ishak \& Haneef 2014). Therefore, understanding the complexities of GD is far more challenging for young Muslims than the people in the West (Saeed et al. 2018). No wonder, that many Muslims are still dubious and question the legitimacy of GD. This article provides a synopsis of transgender people or GD patients - their reality, social and medical status followed by major medical and ethical views and controversies on GD, to the Muslim readers. Moreover, the article will discuss and analyze some key points that are of special interest to the younger generation of 
Muslims based upon our observation and experience in Islamic societies. The tem "young" or "young people" will be used throughout this essay to refer to people who are 16-30 years of age.

\section{METHODS}

A non-systematic literature review was conducted through PubMed, Web of science and Scopus databases to search English language articles that covered topics relevant to our objectives i.e. GD definition, related terminologies, medical management, social and health status of transgender community, medical and ethical controversies on GD. All selected articles were published between the periods of 1960 to 2020 .

\section{DEFINITIONS AND SOME TERMINOLOGIES}

Oftentimes people use the words sex and gender indiscriminately in some cultures, like Middle Eastern or Indian subcontinent, without paying attention to the connotation or the implications thereof. Therefore, it is important to define these two terms for the readers of this article.

Nature has created humans, principally, as males and females, but based on their behavior or gender expression, humans are also categorized as men and women. In most societies, males are defined as men and females as women - the so-called binary system of human existence (Wong 2012). However, in reality and rarely, this idyllic social model is disrupted when a puzzling scenario appears and a male passes himself as a woman and vice versa. Such people are termed as non-binary, gender nonconforming, gender atypical, gender variant or colloquially transgender or trans (Richards et al. 2016, Hyde et al. 2019). Many different variants of transgender people exist to date based on their behavioral profile as shown in Table 1 (American Psychiatric Association 2013).

Notably, not all variants of transgender people suffer from GD as explained later under etiology (Levine 2018). Transgender folks who experience GD are greatly uncomfortable or agonized about the conflict between their gender and natal sex and seek sex change therapy (Joseph et al. 2017). This article is focused exclusively on transgender with GD and any mention of transgender would imply those with GD.

\section{THE REALITY OF GENDER DYSPHORIA (GD)}

People with uncharacteristic gender behavior, lifestyle or mannerism, have existed in human societies since inception and are mentioned in the Scriptures [The Holy Bible: Isaiah 56: 4-5 \& John 7:24; The Holy Quran: 4: 119] (Zurada et al. 2018, The Holy Bible 1989, The Holy Quran). In many Muslim cultures, there is not much awareness about the diversity of sexual and gender configuration, and the intersex, transgender, and homosexual individuals, are all viewed as the same thing, which is not the case (Jami 2005). Homosexual males or females are sexually attracted to members of their own sex but their gender identity is fully congruent with their sex. In contrast, most transgender people are heterosexuals because their sexual orientation is driven by their gender and not the biological sex (Nieder et al. 2011, Fein et al. 2018). Intersex people, on the other hand, have abnormalities of sexual development, and have ambiguous chromosomal or genitalia (Mouriquand et al. 2016).

\section{Etiology of GD}

Gender dysphoria has been an enigma as regards its etiology. Whether transgender behavior is an inherent feature or an acquired one, it is still being investigated. Numerous theories have been proposed to link its origin to genetic, hormonal, neurobiology, psychological or environmental factors (Berglund et al. 2008). The most convincing hypothesis is that alterations in prenatal hormonal exposure to developing fetus might induce some neuronal differentiation, which is responsible for GD (Mouriquand et al. 2016, Swaab 2017).

Scientists also believe that environmental factors, such as family, lifestyle, cultural, and social values might also predispose a person to become transgender (Marantz $\&$ Coates 1991). However, none of the above theories have been proven on concrete grounds and further research is ongoing, to date. It is worthwhile noting that sometimes people adopt conflicting identity, temporarily or permanently for entertainment or commercial reasons and such people typically suffer no dysphoria about living or posing as the other gender (Levine 2018).

Table 1. Definitions of some common gender variants

\begin{tabular}{ll}
\hline Gender Expression & \multicolumn{1}{c}{ Definition } \\
\hline Gender queer or gender fluid & Whose gender identity is unstable \\
Bi-gender & Those who experience two different gender identities \\
Transvestites & Those who cross-dress for psychological satisfaction, but the term is not really \\
& a term used anymore. \\
Transsexuals & Those who are or have already been through sex change therapy, commonly known \\
& as gender confirming surgery. \\
Cis-gender & Whose sex and gender are in harmony by social standards or their interior disposition \\
& is congruent with their exterior demeanor, like majority of the human population. \\
\hline
\end{tabular}




\section{Global Status of Transgender People}

Below is a glimpse of the way transgender people are faring on a global stage, in two categories: socioeconomic status and health status.

\section{Socio-economic status}

A thorough and comprehensive academic review of the literature points to a bitter reality that transgender people are profusely abused, maltreated, disrespected, stigmatized, overtly or covertly, virtually in all societies (Grant et al. 2010, United Nations 2011, Bostwick et al. 2014). Data show that about $90 \%$ of transgender people are harassed and $25 \%$ have experienced physical assault because of their gender expression (Kosciw et al. 2012).

Discrimination to transgender is exhibited everywhere whether it is an educational institution, healthcare center, employment sector or a place of worship (Kosciw et al. 2012, Bostwick et al. 2014). Professor Canales, succinctly describes transgender folks as "the most maligned, misunderstood, and marginalized group" in one of his numerous articles (Canales 2018a,b). Currently, Western societies are recognizing and are steadily becoming more tolerant of transgender issues by implementing trans friendly civil and legal policies, passing non-discrimination laws to provide protections for transgender people in employment, education, and healthcare (Transgender Law and Policy Institute 2012).

\section{Health status and statistics}

Numerous reports have also demonstrated that the transgender population is at 2-3 times higher risk of psychiatric illnesses such as anxiety, depression, social phobia and adjustment disorders compared to their cisgender peers secondary to the host of internal and external stressors shown in Figure 1 (Gómez-Gil et al. 2010, Reisner et al. 2015b). As direct result of experiencing marginalization, transgender people also have a high prevalence of substance abuse and suicidal behavior with $41 \%$ has actually attempted suicide in their lifetimes (Grant et al. 2010). It is also been reported that HIV risk is much higher in transgender population compare to the general population (Wilson et al. 2009).

\section{Transgender people in Muslim countries}

The state of affairs for transgender people in Islamic socities is not any different from the rest of the world, and perhaps it is far worse in some developing Muslim countries. Our literature review discovered that social and economic states of transgender people are deplorable in Malaysia, Indonesia, Pakistan and are marked by poverty, marginalization, abundant stigmatization, hatred, violence, neglect, lack of education, healthcare, employment opportunities etc. (Gibson et al. 2016, Saeed et al. 2018, Shah et al. 2018). High prevalence of human immunodeficiency virus and other sexual transmitted diseases among local transgender people in these developing nations is a major public health issue that have raised international concern (Akhtar et al. 2012, Wong 2012, Gibson et al. 2016, Barmania \& Aljunid 2017, Vijay et al. 2018, Mitchell et al. 2019, Akhtar et al. 2020, Robbins et al. 2020). Unfortunately, most data on transgender people has been reported by a few Muslim countries, i.e. Turkey, Iran, Malaysia, Indonesia, Pakistan, and Nigeria.

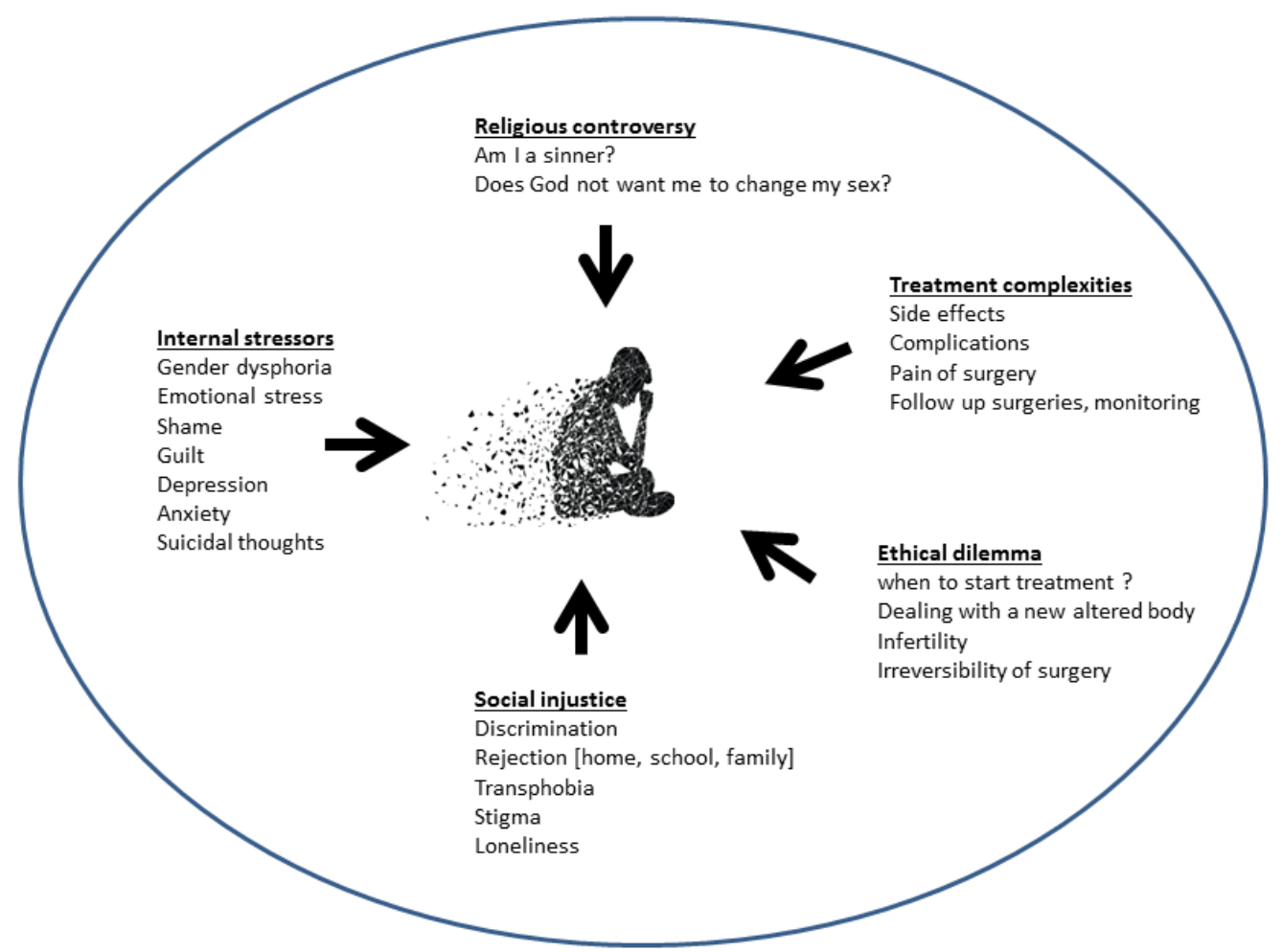

Figure 1. A depiction of the conglomerate of stressors for gender dysphoric patients 
There is minimal or no representation of transgender people from Arab nations or the rest of the Muslim countries indicating a generalized negligence or lack of attention on transgender matters in these countries. To date, only three Islamic countries, Turkey, Iran, and Egypt legally recognize GD as a medical condition and offer medical management or sex change therapies to those seeking ways to align their bodies with their psychological feelings to adjust to society's standards (Turan et al. 2015, Mazen 2017, Valashany et al. 2018). Pakistan has also recently granted its transgender citizens the rights of their gender expression regardless of their natal sex (Shah et al. 2018). Legally, the transgender community does have legitimate rights and a functional support system in Turkey, Iran and Pakistan. Nevertheless, the burden of social stigma and discrimination for transgender people is still a reality and is felt at all levels in these countries (Polat 2005, Saeidzadeh 2016).

\section{VARIOUS VIEWS ON GD AND ITS MANAGEMENT}

Understanding the root causes of the controversy regarding GD is paramount. The debate in medical and ethical disciplines that GD has provoked is extensive. The religious debate on GD is a substantial area and is beyond the scope of this article. Readers are briefly reminded that like Christian and Jews scholars, Islamic religious leaders also hold both conservative and liberal views on GD and its management (Ishak \& Haneef 2014). Except for Egypt, Turkey and Iran, the rest of the Islamic states have prohibited sex change treatment to cure GD.

\section{Medical views and controversies}

Initially, GD was considered a psychiatric condition (Bancroft \& Marks 1968, Green \& Money 1969). However, after years of research, experts in the field are now convinced that GD is neither a mental or psychiatric illness nor a personal choice; rather it is an inherent conflict between one's gender and sex that warrants intervention (Reisner et al. 2015b). Retrospectively, all other modalities including behavioral and psychotherapy approaches attempting to conform patient's feeling of self-perception to align to a person's natal sex have proven unsuccessful (Bancroft \& Marks 1968, Green \& Money 1969).

\section{Evidence based management guidelines}

World Professional Association for Transgender Health [WPATH]," have established and published evidence-based treatment guidelines for GD (Coleman et al. 2012).

According to these guidelines, the management of GD is aimed at alleviating the dysphoria or distress associated with the feelings of gender incongruence rather than attempting to conform patient's feeling of self-perception to align to a person's natal sex (Coleman et al. 2012). Therefore, at present, the gender confirmation or affirmation or sex reassignment therapies (SRT), seem to be the only authentic option in relieving GD (Meyerowitz 2009). Table 2 presents diagnostic criteria for GD in adults and children (Zucker et al. 2016).

It is apparent from a glance at the stepwise sequence of the treatment process shown in Figure 2 that SRT are quite an elaborate process. Given the extensive nature of the SRT, clinicians must ensure that the patient understands the protocols, and the short-term and long-term benefits, difficulties, and consequences of SRT. On the other hand, prescribers are also cautioned that after diagnosis of GD is established, any barriers or restrictions to SRT can culminate in devastating consequence for patients (Gridley et al. 2016, Wright et al. 2018).

Initiation of SRT require meticulous evaluation by at least two health care professionals specializing in sex/gender issues to confirm the diagnosis of GD. After initial evaluation, GD patients are started on hormones treatment. Subsequent to adequate hormone therapy, which normally lasts 1-2 years, patients can proceed for surgeries. Before the surgeries, patient is asked to provide an evidence of social adaptability to a new gender role by dressing and living like a member of the desired sex. After passing all above criteria, only then the patients are deemed fit for surgical procedures (Coleman et al. 2012).

Sex change surgeries are complex, multi-step procedures with a range of major and minor procedures that mandate postsurgical follow-ups and medical care for life (Table 3) (Coleman et al. 2012).

Table 2. Diagnostic criteria for gender dysphoric children and adolescents or adults

\begin{tabular}{|c|c|c|}
\hline & Children & lolescents/Adults \\
\hline Common diagnostic features & $\begin{array}{l}\text { Presence of a marked conflict between one' } \\
\text { combined with significant distress and function }\end{array}$ & $\begin{array}{l}\text { 's gender and the assigned sex at birth } \\
\text { nal impairment for at least } 6 \text { months. }\end{array}$ \\
\hline Age specific features & $\begin{array}{l}\text { - Insistence on being the other sex } \\
\text { - Showing strong predilection for choices } \\
\text { in clothing, toys, and playmates similar } \\
\text { to the opposite sex children }\end{array}$ & $\begin{array}{l}\text { The strong urges (desires), } \\
\text { - To be treated as the person of the } \\
\text { other sex } \\
\text { - A strong desire for the primary and/or } \\
\text { secondary sex characteristics of the } \\
\text { other sex } \\
\text { - To get rid of one's sexual features }\end{array}$ \\
\hline
\end{tabular}




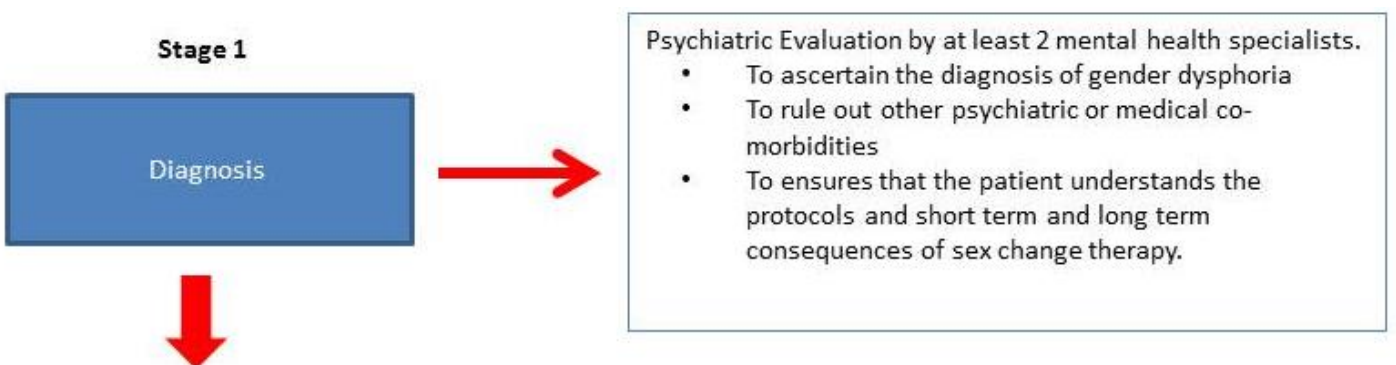

Stage 2
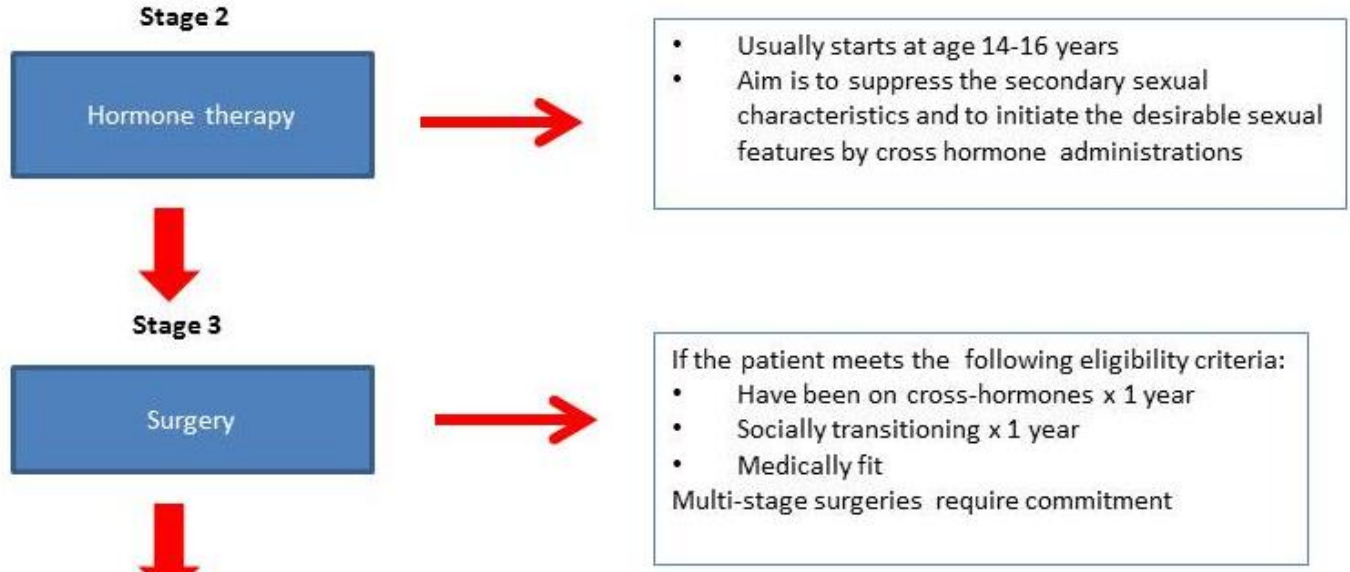

Follow up [Life long monitoring and cross-hormone administration]

Figure 2. World Professional Association for Transgender Health [WPATH] recommended stepwise approach for GD management

Table 3. A few examples of common transgender surgeries

\begin{tabular}{lll}
\hline Surgical Procedures & Male to Female & Female to Male \\
\hline Major & - Penectomy & - Mastectomy Hysterectomy/Oophorectomy \\
& - Orchiectomy & - Vaginectomy \\
& - Vaginoplasty & - Metoidioplasty Phalloplasty \\
Cosmetics & - Vulvoplasty & - Scrotoplasty \\
& - Liposuction/Lipo filling & - Liposuction/Lipo filling \\
& - Voice surgery & - Voice surgery \\
& - Gluteal augmentation & - Thyroid cartilage enhancement \\
& - Hair reconstruction & - Fec-toral implants \\
& & - Rorehead or check augmentation \\
\end{tabular}

The WPATH has set a very well-defined and standardized criterion for the diagnosis and treatment of SRT. The aim is to ensure that only transgender patients with intensely painful psychological feelings arising from the sex and gender mismatch are offered SRT. Simultaneously, it is also desired that GD patients should not be denied their right of changing their sex to normalize their lives.

\section{Medical concerns with sex reassignment therapies}

Successful SRT are, undoubtedly, commendable scientific achievements in restoring a person's gender dysphoric feeling; they are not without risk and caveats. It is wise to briefly discuss some points of concerns associated with SRT.

Hormonal therapies are reversible and seemingly serve to reinstate the psychological well-being of children, youth and young adults (Corley et al. 1981, Hembree et al. 2017). However, the side effects of hormone therapies, albeit manageable require close monitoring. Current safety data on the hormone agents has mixed findings, though studies showing benefits outnumber the studies showing harm or serious side effects (Viner 
et al. 2005, Weinand \& Safer 2015, Hembree et al. 2017). Similarly, the outcomes of sex change surgeries are highly questionable with some studies showing improvement in patients' quality of life and life satisfaction and others demonstrating high mortality rates, dissatisfaction, substance abuse, and poor quality of life with physical, and role limitations even 12-15 years after surgeries (Kuhn et al. 2009, Mur et al. 2010, Wierckx et al. 2011, Simonsen et al. 2016, Zeluf et al. 2016, Simbar et al. 2018, Fallahtafti et al. 2019). However, the surgical outcome depends on the nature of the procedure involved and the general health status of the patient (Djordjevic et al. 2019, Schardein et al. 2019).

Unfortunately, until now we lack reliable, welldesigned, long-term studies with statistically significant data. Most of the studies in this arena suffer from methodological limitations, lack of right matching control, or small sample size inadequacies, which render conclusion less reliable (Levine 2018). All things considered, further investigation is required to gain clarity on the durable outcomes of SRT.

\section{Ethical views and limitations}

The complexity of GD does not culminate merely in scientific domains but extends to the ethics surrounding its management as well (Levine 2018). Followings are some points of ethical concern:

\section{Optimum time to start therapy}

The first ethical impasse to manage GD is to determine the right time to initiate therapy in children or adolescents. Not only the children's autonomy is questionable at immature age; it is inconclusive if children are able to fully comprehend the repercussions of the medical and surgical interventions to give their informed consent (Bizic et al. 2018). On the other hand, delaying the treatment is highly likely to intensify the dysphoria related depression, anxiety, suicidal ideation, and subject the trans person to embarrassment, harassment, and feeling of incompleteness (Giordano 2008).

\section{Post-surgery regrets}

There are reports and incidents of people experiencing postsurgical regrets. The major risk factors are named as wrong GD diagnosis, poor psychiatric evaluation, unsatisfactory aesthetical or functional outcome of the newly created sex organs, lack of family support and feelings of guilt due to religious affiliations (Djordjevic et al. 2016). Unlike the hormone therapy, surgery is irreversible and this fact heightened the sensitivity of surgical interventions.

\section{Infertility is a concern for patients}

A highly emotional ethical predicament for transgender young people is to choose between their sex transition and retaining their reproduction ability. Not only cross-hormone therapy temporarily impedes the infertility, surgical hysterectomy or orchiectomy can permanently deprive trans youth of the potential to bear their own off springs (Bizic et al. 2018). Since a vast majority of transgender adults aspire to have children, WPATH guidelines mandate that patients be fully and thoroughly informed of this major consequence of the SRT. Fortunately, some alternative options such as cryopreservation of the oocytes, sperms, or gonadal tissues are available that transgender can count on to procreate after SRT (Bizic et al. 2018, Ellis et al. 2015).

Briefly, opting for the surgery is a significant ethical dilemma for the GD patients, their families and as well as the surgeons.

\section{DISCUSSION OF A RATIONAL APPROACH TO GD CONTROVERSIES}

In this section, we will discuss and try to logically explain the perplexing questions that linger in the minds of many in the Eastern and Middle Eastern culture.

\section{Is GD real?}

Since scientists do not know with exact certitude the causes of GD, it is difficult to pinpoint its origins. Well, after seeing so many worldwide cases, it is difficult to deny the legitimacy of GD. The etiology of many other diseases such as multiple sclerosis, fibromyalgia pain, Alzheimer disease, cancer, and the primary hypertension is also unknown. Therefore, it should not be difficult for us to acknowledge another "mystery condition" like GD. The overall global prevalence of GD patients is unknown due to underreporting and possible shame associated with the condition in Islamic culture (Shumer 2016). Still, data obtained from Western countries demonstrate that a significant number of people selfidentify themselves to be transgender people, for instance, $0.6-1.4 \%$ in USA; $0.4 \%$ in UK and 0.03 $0.08 \%$ in Netherland, respectively (Van et. al. 1996, Conron et al. 2012, Ellis et al. 2015). Among Muslim countries, Iran and Turkey have published sizable number of articles on GD. With all of that information, it is hard to deny the legitimacy of GD. People might disagree whether GD is a physical, mental, or psychological issue, but it a real and legitimate medical perplexity.

\section{What is the right treatment for GD?}

Seemingly, most of the controversy, dilemma, and ethical concerns about GD revolve around its proper therapy; liberal-minded people corroborate the scientific facts and approve the evidence-based therapy for GD, while conservatives voice against SRT principally on religious or ethical grounds. Essentially, there are only two possible treatment options: (1) change the mind [psychotherapy] or (2) change the sex [hormone and surgical treatments]. 


\section{Is psychotherapy the right approach?}

Perhaps, conservatives would suggest that counseling and psychotherapy based conversion therapies are more appropriate for GD patient [to align their feelings to their natal sex]. As previously mentioned, studies have proven the futility of all such therapies including behavioral, spiritual, religious, and electro-convulsant techniques or the use of psychiatric medicines. Cultures that promote coercion policy to suppress any atypical thoughts result in seeing GD patients who suppress and conceal their gender expression and suffer internally (Reisner et al. 2015a). This does not seem to be a viable solution of ethical care or patient care within the medical community.

Interestingly, some studies do suggest that $10-20 \%$ of children exhibiting GD like symptoms grow out of it during their adolescent or adult years (Hembree 2011). However, it would be wise to remember that our knowledge of GD is still evolving and much is still unknown. It is possible that those percentages of children were misdiagnosed and were transiently influenced by environmental factors.

\section{Is sex reassignment therapy the right approach?}

Sex reassignment therapies are exactly the medical procedure that a person struggling with GD desires; science supports such treatment and religious progressives agree. If SRT can be accomplished uneventfully, it will be an ideal scenario. But given the complications, regrets and guilt with the therapy, there is certainly a need to develop better, safer scientific techniques for SRT. It is wise to keep in mind that the two major causes of regrets after surgery or before surgery are the guilt of disobeying God and familial rejection, and not the SRT per se (Safavifar 2016). Both of these factors are only related to our hardline attitude toward SRT. Reports also indicate that the process of SRT, however, can by facilitated by the family support and care, not to mention the empathy, compassion, understanding, kindness, and love of the whole community that can make the entire process much more endurable (Polat 2005, Fallahtafti et al. 2019).

Hopefully, the more reliable SRT procedures will be invented in the future. Good news is that the stem cells are on our door steps and scientists have already formed autologous organs in laboratories (Iannaccone et al. 2018, Becherucci et al. 2018). It is only a matter of time when organs can be regenerated and implanted to humans (Atala 2013). We should be hopeful that humans can achieve this.

\section{REFLECTION}

This point is a moment of reflection for all to ponder. Above, illustrates the way transgender people have been and are still being treated in the world. Abuse, violence, injustice, discrimination, neglect, rejection, deprivation are all part of transgender lives only because of their atypical appearance. It is only now that the medical science has provided transgender people the opportunity to amend their misaligned bodies to live normal lives and blend in a society. Unfortunately, in many Muslim societies transgender folks are ignored altogether; their existence is known, but no steps are taken to normalize them in society or alleviate their plight.

Transgender people deserved to be given the choice to make decisions about their lives. It is time that we reconsider our behavior toward trans people, and change our minds on the ways we can accept them and assist them in their journey to treatment.

\section{FUTURE DIRECTION}

Two vital factors contribute to pitiful conditions for transgender people in the Muslim world: generalized unawareness and myopic religious views. Both factors demand a high caliber, multi-faceted, research on the transgender issues in Muslim countries. Scientific studies and theological research to highlight the root causes of transgender or GD, identify the merits or demerits of SRT, and to address the physical or psychological needs of the transgender people should be a research priority for Muslim countries. Collaborative research and dialogue will raise public understanding of transgender conditions, and will set the foundation for social reforms in Muslim countries to grant transgender people their human rights.

\section{CONCLUSION}

Gender dysphoria has always been a puzzling and controversial phenomenon worldwide.

In most Muslim countries, GD has been considered a far more complex and culturally sensitive subject as compared to the West. The discussion of GD treatment in these Muslim countries has been ignored since long. Consequently, in the trans community there is suffering on many counts, in silence, for years without any platform to voice their physical and psychological needs. Recently, Muslim young people seem to be interested in broaching upon transgender related topics. Through this article, we offer young people a glimpse into GD along with the global status of those living it, and the current medical and ethical dilemma surrounding it. We hope this discussion is logical, and our Muslim readers will be able to glean that GD is a real medical issue and deserves treatment. Whether the medical procedures are complicated, reliable, right or wrong, under the circumstances, we would be wise to let the trans person decide for themselves and be supportive to them either way. Raising more public awareness, initiating active research, and changing "our minds," rather than that of GD patients, can bring forth a swift, happy, and peaceful solution to this suffering minority population. 


\section{Acknowledgements:}

Authors highly acknowledge the contribution and assistance of Ms. Amal Turikham Alghamdi for helping the literature search and short listing relevant articles from Muslim countries and Ms. Akira Jbeen for editing this manuscript, preparing references and providing technical assistance.

\section{Conflict of interest: None to declare.}

\section{Contribution of individual authors:}

Najla Taslim conceptualized, designed and drafted this article.

Arthur D. Canales provided mentorship supervision for the writing and conceptualization of this article besides editing and revising the document.

Shrooq Mohamed T. Alshehab provided insightful ideas, helped in literature search and articles selection.

\section{References}

1. Akhtar H, Badshah Y, Akhtar S, Kanwal N, Akhtar MN, Zaidi NU, Qadri I: Prevalence of human immunodeficiency virus infection among transgender men in Rawalpindi (Pakistan). Virol J 2012; 9:229. https://virologyj. biomedcentral.com/articles/10.1186/1743-422X-9-229

2. Akhtar M\& Bilour N: State of Mental Health Among Transgender Individuals in Pakistan: Psychological Resilience and Self-esteem. Community Ment Health J 2020; 56:626634. https://link.springer.com/article/10.1007/s10597-01900522-5

3. American Psychiatric Association. What is Gender Dysphoria? 2016. Available at https://www.psychiatry.org/ patients-families/gender-dysphoria/what-is-gender-dysphoria

4. American Psychiatric Association: Diagnostic and Statistical Manual of Mental Disorders. 5th ed. (DSM-5). Washington, DC: American Psychiatric Association, 2013

5. Atala A: Adult Stem Cell Bladder Regeneration. [March 2013]. Available at https://www.youtube.com/watch? $v=$ XzHheilkpok

6. Bancroft J \& Marks I: Electric aversion therapy of sexual deviations. Proc Roy Soc Med 1968; 61:30-2. https://www.ncbi.nlm.nih.gov/pmc/articles/PMC1902433/

7. Barmania $S$ \& Aljunid SM: Transgender women in Malaysia, in the context of HIV and Islam: a qualitative study of stakeholders' perceptions. BMC Int Health Hum Rights 2017; 17:30. https://bmcinthealthhumrights.biomedcentral. com/articles/10.1186/s12914-017-0138-y

8. Becherucci F, Mazzinghi B, Allinovi M, Angelotti ML, Romagnani P: Regenerating the kidney using human pluripotent stem cells and renal progenitors. Expert Opin Biol Ther 2018; 18:795-806. https://doi.org/10.1080/ 14712598.2018 .1492546

9. Berglund H, Lindström P, Dhejne-Helmy C, Savic I: Male-to-female transsexuals show sex-atypical hypothalamus activation when smelling odorous steroids. Cereb Cortex 2008; 18: 1900-8. DOI: 10.1093/cercor/bhm216

10. Bizic MR, Jeftovic M, Pusica S, Stojanovic B, Duisin D, Vujovic S et al.: Gender Dysphoria: Bioethical Aspects of Medical Treatment. Biomed Res Int 2018.

https://www.hindawi.com/journals/bmri/2018/9652305/
11. Bostwick WB, Boyd CJ, Hughes TL, West BT \& McCabe $S E$ : Discrimination and mental health among lesbian, gay, and bisexual adults in the United States. Am J Orthopsychiatry 2014; 84:35-45. DOI: 10.1037/h0098851

12. Canales AD: Ministry to Transgender Teenagers (Part One): Pursuing Awareness and Understanding about Trans Youth. J Pastoral Care Counsel 2018; 72: 195-201. DOI: 10.1177/1542305018790216

13. Canales AD: Ministry to Transgender Teenagers (Part Two): Providing Pastoral Care, Support, and Advocacy to Trans Youth. Journal of Pastoral Care \& Counseling 2018; 72: 251-6. https://doi.org/10.1177/1542305018790277

14. Christine Jorgensen. [Accessed December 16, 2015]; Available at http://www.christinejorgensen.org

15. Coleman E, Bockting $W$, Botzer M, Cohen-Kettenis $P$, DeCuypere G, Feldman J et al.: Standards of care for the health of transsexual, transgender, and gender nonconforming people, version 7. Int J Transgenderism 2012; 13: 165-232. https://doi.org/10.1080/15532739.2011.700873

16. Conron KJ, Scott G, Stowell GS \& Landers SJ: Transgender health in Massachusetts: results from a household probability sample of adults. Am J Public Health 2012; 102: 118-122. DOI: 10.2105/AJPH.2011.300315

17. Corley KP, Valk TW, Kelch RP \& Marshall JC: Estimation of GnRH pulse amplitude during pubertal development. Pediatr Res 1981; 15:157-162. https://doi.org/10.1203/00006450-198102000-00015

18. Djordjevic ML, Bizic MR, Duisin D, Bouman MB, Buncamper M: Reversal Surgery in Regretful Male-toFemale Transsexuals After Sex Reassignment Surgery. J Sex Med 2016; 13: 1000-1007. DOI: 10.1016/j.jsxm.2016.02.173

19. Djordjevic ML, Stojanovic B \& Bizic M: Metoidioplasty: techniques and outcomes. Transl Androl Urol 2019; 8: 248-253. DOI: 10.21037/tau.2019.06.12

20. Ellis SJ, Bailey L \& McNeil J: Trans people's experiences of mental health and gender identity services: a UK Study. $J$ Gay Lesbian Ment Health 2015; 19: 4-20. https://doi.org/10.1080/19359705.2014.960990

21. Fallahtafti E, Nasehi $M$, Rasuli R, Farhud DD, Pourebrahim T, Zareeeimahmoodabadi H: Happiness and Mental Health in Pre-Operative and Post-Operative Transsexual People. Iran J Public Health 2019; 48: 2277 2284. PMCID: PMC6974860

22. Fein LA, Salgado CJ, Sputova K, Estes CM\& Medina CA: Sexual Preferences and Partnerships of Transgender Persons Mid- or Post-Transition. J Homosex 2018; 65: 659-671. DOI: 10.1080/00918369.2017.1333808

23. Gibson BA, Brown SE, Rutledge R, Wickersham JA, Kamarulzaman A, Altice FL: Gender identity, healthcare access, and risk reduction among Malaysia's mak nyah community. Glob Public Health 2016; 11: 1010-1025. DOI: 10.1080/17441692.2015.1134614

24. Giordano S: Ethics of management of gender atypical organization in children and adolescents. International Public Health Policy and Ethics 2008: 249-272. https://doi.org/10.1007/978-1-4020-8617-5_15

25. Gómez-Gil E, Esteva I, Almaraz MC, Pasaro E, Segovia S, Guillamon A: Familiality of gender identity disorder in non-twin siblings. Arch Sex Behav 2010; 39: 546-552. DOI: 10.1007/s10508-009-9524-4

26. Grant JM, Mottet LA, Tanis JD, Herman JL, Harrison J \& Keisling M: National transgender discrimination survey 
report on health and health care. National Center for Transgender Equality; National Gay and Lesbian Task Force 2010. https://transequality.org/issues/resources/ national-transgender-discrimination-survey-full-report

27. Green $R \&$ Money J: Transsexualism and sex reassignment. Baltimore, MD: Johns Hopkins University Press, 1969.

28. Gridley SJ, Crouch JM, Evans Y, Eng W, Antoon E, Lyapustina M et al.: Youth and Caregiver Perspectives on Barriers to Gender-Affirming Health Care for Transgender Youth. J Adolesc Health 2016; 59: 254-261. https://doi.org/10.1016/j.jadohealth.2016.03.017

29. Hembree WC, Cohen-Kettenis PT, Gooren L, Hannema SE, Meyer WJ, Murad MH et al.: Endocrine Treatment of Gender-Dysphoric/Gender-Incongruent Persons: An Endocrine Society Clinical Practice Guideline. J Clin Endocrinol Metab 2017; 102:3869-3903. DOI: $10.1210 / j c .2017-01658$

30. Hembree WC: Guidelines for pubertal suspension and gender reassignment for transgender adolescents. Child Adolesc Psychiatr Clin N Am 2011; 20:725-732. DOI: 10.1016/j.chc.2011.08.004

31. Hyde JS, Bigler RS, Joel D, Tate CC \& van Anders SM: The future of sex and gender in psychology: Five challenges to the gender binary. Am Psychol 2019; 74: 171-193. DOI: 10.1037/amp0000307

32. Iannaccone PM, Galat V, Bury MI, Ma YC \& Sharma AK: The utility of stem cells in pediatric urinary bladder regeneration. Pediatr Res 2018; 83: 258-266. DOI: 10.1038/pr.2017.229

33. Ishak MS \& Haneef SS: Sex reassignment technology: the dilemma of transsexuals in Islam and Christianity. J Relig Health 2014; 53:520-537. DOI: 10.1007/s10943-012-9656-z

34. Jami H: Condition and Status of Hijras (Transgender, Transvestites Etc.) in Pakistan: Country Report. Sexualities, Genders and Rights in Asia: 1st International Conference of Asian Queer Studies. Bangkok, Thailand; 2005. http://hdl.handle.net/1885/8669

35. Joseph A, Cliffe C, Hillyard $M$ \& Majeed A: Gender identity and the management of the transgender patient: a guide for non-specialists. J R Soc Med 2017; 110: 144152. DOI: 10.1177/0141076817696054

36. Kosciw JG, Greytak EA, Bartkiewicz MJ, Boesen MJ, Palmer NA: The 2011 National School Climate Survey: The Experiences of Lesbian, Gay, Bisexual and Transgender Youth in Our Nation's Schools. Gay, Lesbian \& Straight Education Network 2012. ERIC Number: ED535177

37. Kuhn A, Bodmer C, Stadlmayr W, Kuhn P, Mueller MD \& Birkhäuser M: Quality of life 15 years after sex reassignment surgery for transsexualism. Fertil Steril 2009; 92: 1685-1689. DOI: 10.1016/j.fertnstert.2008.08.126

38. Levine SB: Ethical Concerns About Emerging Treatment Paradigms for Gender Dysphoria. J Sex Marital Ther 2018; 44: 29-44. DOI: 10.1080/0092623X.2017.1309482

39. Marantz $S$ \& Coates $S$ : Mothers of boys with gender identity disorder: a comparison of matched controls. $\mathrm{J} \mathrm{Am}$ Acad Child Adolesc Psychiatry 1991; 30: 310-315. https://doi.org/10.1097/00004583-199103000-00022

40. Mazen IA: Clinical Management of Gender in Egypt: Intersexuality and Transsexualism. Arch Sex Behav 2017; 46: 369-372. DOI: 10.1007/s10508-016-0842-z

41. Meyerowitz JJ: How sex changed: A history of transsexuality in the United States. Cambridge, MA: Harvard University Press, 2009
42. Mitchell E, Lazuardi E, Rowe E, Anintya I, Wirawan DN, Wisaksana $R$ et al.: Barriers and Enablers to HIV Care Among Waria (Transgender Women) in Indonesia: A Qualitative Study. AIDS Educ Prev 2019; 31: 538-552. DOI: 10.1521/aeap.2019.31.6.538

43. Mouriquand PD, Gorduza DB, Gay CL, Meyer-Bahlburg $H F$, Baker L, Baskin LS et al.: Surgery in disorders of sex development (DSD) with a gender issue: If (why), when, and how?. J Pediatr Urol 2016; 12:139-49.

DOI: 10.1016/j.jpurol.2016.04.001

44. Mur Murad MH, Elamin MB, Garcia MZ, Mullan RJ, Murad A, Erwin PJ et al.: Hormonal therapy and sex reassignment: a systematic review and meta-analysis of quality of life and psychosocial outcomes. Clin Endocrinol (Oxf) 2010; 72: 214-231. DOI: 10.1111/j.1365-2265. 2009.03625.x

45. National Gay and Lesbian Task Force: Scope of Explicitly Transgender-Inclusive Anti-Discrimination Laws. Transgender Law and Policy Institute, 2008. https://www.loc.gov/item/lcwaN0028132/

46. Nieder TO, Herff M, Cerwenka S, Preuss WF, CohenKettenis PT, De Cuypere G et al.: Age of onset and sexual orientation in transsexual males and females. J Sex Med 2011; 8:783-791. https://doi.org/10.1111/j.1743-6109. 2010.02142.x

47. Polat A, Yuksel S, Discigil AG \& Meteris H: Family attitudes toward transgendered people in Turkey: experience from a secular Islamic country. Int $J$ Psychiatry Med 2005; 35: 383-393. DOI: 10.2190/BHLYK1ML-JDCB-H04W.

48. Robbins SJ, Dauda W, Kokogho A, Ndembi N, Mitchell A, Adebajo $S$, Gaydos CA, Peel $S$, Ramadhani $H O$, Robb ML, Baral SD, Ake JA, Charurat ME, Crowell TA, Nowak RG; TRUST/RV368 Study Group. Oral sex practices among men who have sex with men and transgender women at risk for and living with HIV in Nigeria. PLoS One 2020 Sep 4; 15:e0238745. DOI: 10.1371/journal.pone.0238745.

49. Reisner SL, Hughto JM, Dunham EE, Heflin KJ, Begenyi $J B$, Coffey-Esquivel $J$ et al.: Legal Protections in Public Accommodations Settings: A Critical Public Health Issue for Transgender and Gender-Nonconforming People. Milbank Q 2015a; 93:484-515. DOI: 10.1111/14680009.12127

50. Reisner SL, Vetters R, Leclerc M, Zaslow S, Wolfrum S, Shumer D et al.: Mental health of transgender youth in care at an adolescent urban community health center: a matched retrospective cohort study. J Adolesc Health 2015b; 56: 274-279. DOI: 10.1016/j.jadohealth.2014.10.264

51. Richards C, Bouman WP, Seal L, Barker MJ, Nieder TO \& T'Sjoen G: Non-binary or genderqueer genders. Int Rev Psychiatry 2016; 28: 95-102. DOI: $10.3109 / 09540261.2015 .1106446$

52. Saeed A, Mughal U \& Farooq S: It's Complicated: Sociocultural factors and the Disclosure Decision of Transgender Individuals in Pakistan. J Homosex 2018; 65: 1051-1070. DOI: 10.1080/00918369.2017.1368766

53. Saeidzadeh, Z: Transsexuality in Contemporary Iran: Legal and Social Misrecognition. Fem Leg Stud 2016; 24: 249-272. https://doi.org/10.1007/s10691-016-9332-x

54. Safavifar F, Eftekhar M, Alavi K, Negarandeh R, Jalali AH, Eftekhar M: Religious experiences of Iranian transgenders: A qualitative study. Med J Islam Repub Iran 2016; 30: 385. PMCID: PMC4972060 
55. Schardein JN, Zhao LC \& Nikolavsky D: Management of Vaginoplasty and Phalloplasty Complications. Urol Clin North Am 2019; 46: 605-618. doi:10.1016/j.ucl.2019.07.012

56. Shah HBU, Rashid F, Atif I, Hydrie MZ, Fawad MW, Muzaffar HZ et al.: Challenges faced by marginalized communities such as transgenders in Pakistan. Pan Afr Med J 2018; 30: 96. DOI:10.11604/pamj.2018.30.96.12818

57. Shumer DE, Nokoff NJ \& Spack NP: Advances in the Care of Transgender Children and Adolescents. Adv Pediatr 2016; 63: 79-102. DOI: 10.1016/j.yapd.2016.04.018

58. Simbar M, Nazarpour S, Mirzababaie M, Emam Hadi MA, Ramezani Tehrani F, Alavi Majd H: Quality of Life and Body Image of Individuals with Gender Dysphoria. J Sex Marital Ther 2018; 44: 523-532. doi: 10.1080/0092623X.2017.1419392

59. Simonsen RK, Hald GM, Kristensen E, Giraldi A: LongTerm Follow-Up of Individuals Undergoing Sex-Reassignment Surgery: Somatic Morbidity and Cause of Death. Sex Med 2016; 4: e60-e68. DOI: 10.1016/j.esxm.2016.01.001

60. Swaab DF: Sexual differentiation of the brain and behavior. Best Pract Res Clin Endocrinol Metab 2007; 21:431-444. doi: 10.1016/j.beem.2007.04.003

61. The Holy Bible: Containing the Old and New Testaments. Michigan: Zondervan Publishing House, 1989.

62. The Holy Quran in English and Arabic, with Recitations: https://www.quranful.com/

63. Transgender Law and Policy Institute: US jurisdictions with laws prohibiting discrimination on the basis of gender identity or expression. Transgender Law and Policy Institute 2012. https://www.loc.gov/item/lcwaN0028132/

64. Turan Ş, Poyraz CA, Ince E, Sakall-Kani A, Emül HM, Duran A: Cinsiyet Değiştirme Ameliyatı Için Psikiyatri Kliniğine Bașvuran Transseksüel Bireylerin Sosyodemografik ve Klinik Özellikleri [Sociodemographic and Clinical Characteristics of Transsexual Individuals who Applied to a Psychiatry Clinic for Sex Reassignment Surgery]. Turk Psikiyatri Derg 2015; 26:153-160. https://kutuphane.dogus. edu.tr/ mvt/pdf.php?.pdf $=0017602 \& \operatorname{lng}=1$

65. United Nations: Discriminatory Laws and Practices and Acts of Violence Against Individuals Based on their Sexual Orientation and Gender Identity. Report of the United Nations High Commissioner for Human Rights 2011. Available at: http://www2.ohchr.org/english/bodies/ hrcouncil/docs/19session/A.HRC.19.41_English.pdf

66. Valashany BT \& Janghorbani M: Quality of life of men and women with gender identity disorder. Health Qual Life Outcomes 2018; 16:167. https://doi.org/10.1186/s12955018-0995-7
67. Van Kesteren PJ, Gooren LJ \& Megens JA: An epidemiological and demographic study of transsexuals in the Netherlands. Arch Sex Behav 1996; 25: 589-600. doi: 10.1007/BF02437841

68. Viner RM, Brain C, Carmichael P \& Di Ceglie D: G200 sex on the brain: dilemmas in the endocrine management of children and adolescents with gender identity disorder. Arch Dis Child 2005; 90. https://doi.org/10.2147/AHMT.S135432

69. Vijay A, Earnshaw VA, Tee YC, Pillai V, White Hughto JM, Clark K, Kamarulzaman A et al.: Factors Associated with Medical Doctors' Intentions to Discriminate Against Transgender Patients in Kuala Lumpur, Malaysia. LGBT Health 2018; 5: 61-68. DOI: 10.1089/lgbt.2017.0092

70. Weinand JD \& Safer JD: Hormone therapy in transgender adults is safe with provider supervision: A review of hormone therapy sequelae for transgender individuals. $J$ Clin Transl Endocrinol 2015; 2: 55-60.

DOI: 10.1016/j.jcte.2015.02.003

71. Wierckx K, Elaut E, Van Caenegem E, Van De Peer F, Dedecker D, Van Houdenhove E et al.: Sexual desire in female-to-male transsexual persons: exploration of the role of testosterone administration. Eur $J$ Endocrinol 2011; 165: 331-337. https://doi.org/10.1530/EJE-11-0250

72. Wilson EC, Garofalo R, Harris RD, Herrick A, Martinez $M$, Martinez $J$ et al.: Transgender female youth and sex work: HIV risk and a comparison of life factors related to engagement in sex work. AIDS Behav 2009; 13: 902-913. DOI: $10.1007 /$ s10461-008-9508-8

73. Wong Y: Islam, sexuality, and the marginal positioning of Pengkids and their girlfriends in malaysia. J Lesbian Stud 2012; 16: 435-448. doi: 10.1080/10894160.2012.681267

74. Wright T, Candy B \& King M: Conversion therapies and access to transition-related healthcare in transgender people: a narrative systematic review. BMJ Open 2018; 8. http://dx.doi.org/10.1136/bmjopen-2018-022425

75. Zeluf G, Dhejne C, Orre C, Mannheimer LN, Deogan C, Höijer $J$ et al.: Health, disability and quality of life among trans people in Sweden-a web-based survey. BMC Public Health 2016; 16:903. https://doi.org/10.1186/s12889-0163560-5

76. Zucker KJ, Lawrence AA \& Kreukels BP: Gender Dysphoria in Adults. Annu Rev Clin Psychol 2016; 12: 217-247. https://doi.org/10.1146/annurev-clinpsy-021815093034

77. Zurada A, Salandy S, Roberts W, Gielecki J, Schober J \& Loukas M: The evolution of transgender surgery. Clin Anat 2018; 31: 878-886. https://doi.org/10.1002/ca.23206

Correspondence:

Assistant professor Najla Taslim, PhD

Department of Pharmacology, College of Clinical Pharmacy, Imam Abdulrahman bin Faisal University Dammam

PO box 1982, 31442, Saudi Arabia

E-mail:ntakbar@iau.edu.sa 